\title{
2010s-09 \\ Does a Specific Union Impact on Wage Increases? Evidence from Canada, 1985-2007
}

\author{
Édison Roy César, François Vaillancourt
}

Série Scientifique
Scientific Series

\section{Montréal}

\author{
Février 2010
}

(C) 2010 Édison Roy César, François Vaillancourt. Tous droits réservés. All rights reserved. Reproduction partielle permise avec citation du document source, incluant la notice (C).

Short sections may be quoted without explicit permission, if full credit, including (C) notice, is given to the source.
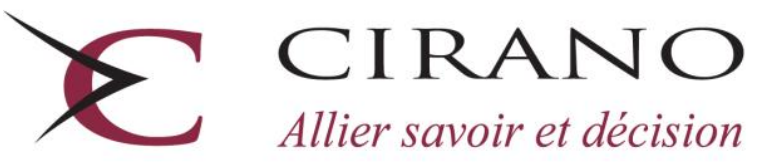

Allier savoir et décision

Centre interuniversitaire de recherche en analyse des organisations 


\section{CIRANO}

Le CIRANO est un organisme sans but lucratif constitué en vertu de la Loi des compagnies du Québec. Le financement de son infrastructure et de ses activités de recherche provient des cotisations de ses organisations-membres, d'une subvention d'infrastructure du Ministère du Développement économique et régional et de la Recherche, de même que des subventions et mandats obtenus par ses équipes de recherche.

CIRANO is a private non-profit organization incorporated under the Québec Companies Act. Its infrastructure and research activities are funded through fees paid by member organizations, an infrastructure grant from the Ministère du Développement économique et régional et de la Recherche, and grants and research mandates obtained by its research teams.

\section{Les partenaires du CIRANO}

Partenaire majeur

Ministère du Développement économique, de l'Innovation et de l'Exportation

\section{Partenaires corporatifs}

Banque de développement du Canada

Banque du Canada

Banque Laurentienne du Canada

Banque Nationale du Canada

Banque Royale du Canada

Banque Scotia

Bell Canada

BMO Groupe financier

Caisse de dépôt et placement du Québec

DMR

Fédération des caisses Desjardins du Québec

Gaz Métro

Hydro-Québec

Industrie Canada

Investissements PSP

Ministère des Finances du Québec

Power Corporation du Canada

Raymond Chabot Grant Thornton

Rio Tinto

State Street Global Advisors

Transat A.T.

Ville de Montréal

\section{Partenaires universitaires}

École Polytechnique de Montréal

HEC Montréal

McGill University

Université Concordia

Université de Montréal

Université de Sherbrooke

Université du Québec

Université du Québec à Montréal

Université Laval

Le CIRANO collabore avec de nombreux centres et chaires de recherche universitaires dont on peut consulter la liste sur son site web.

Les cahiers de la série scientifique (CS) visent à rendre accessibles des résultats de recherche effectuée au CIRANO afin de susciter échanges et commentaires. Ces cahiers sont écrits dans le style des publications scientifiques. Les idées et les opinions émises sont sous l'unique responsabilité des auteurs et ne représentent pas nécessairement les positions du CIRANO ou de ses partenaires.

This paper presents research carried out at CIRANO and aims at encouraging discussion and comment. The observations and viewpoints expressed are the sole responsibility of the authors. They do not necessarily represent positions of CIRANO or its partners. 


\title{
Does a Specific Union Impact on Wage Increases? Evidence from Canada, 1985-2007
}

\author{
Édison Roy César * François Vaillancourt ${ }^{\dagger}$
}

\begin{abstract}
Résumé / Abstract
L'objectif de ce cahier est d'examiner l'impact d'une affiliation syndicale spécifique sur l'augmentation des salaires négociés, étant donné la syndicalisation. Les données sont l'ensemble des conventions collectives de 500 employés et plus qui ont été signées au Québec $(\mathrm{N}=632)$ et en Ontario $(\mathrm{N}=1349)$ durant la période 1985-2007. Le modèle utilisé est une équation salariale typique avec le taux d'augmentation salariale annualisé comme variable dépendante et quatre variables dichotomiques pour les syndicats spécifiques, l'IPC et le taux de chômage retardée de deux périodes par rapport à la signature, la présence ou non d'une clause d'ajustement au coût de la vie et 18 variables de secteur industriel. Nous ne trouvons sauf pour une exception aucun résultat indiquant qu'un syndicat obtient des augmentations plus élevées qu'un autre.
\end{abstract}

Mots clés : salaires syndicats, conventions collectives

The purpose of this note is to examine the effect of belonging to a specific union on negotiated wage increases, given unionisation status. The data consist of all collective agreements with more than 500 employees, which were signed in Quebec $(N=632)$ or Ontario $(N=1349)$ during the 1985-2007 period. The model used is a standard wage equation with the negotiated rate of increase of base wages, annualized as the dependent variable and four dichotomous variables for a specific union, the CPI and the unemployment rate two quarters before the collective agreements, the presence or not of a cost of living agreements in the collective agreement and eighteen industrial dichotomous variables. We find with one exception no evidence that one union is better than another in obtaining higher wage growth.

Keywords: Unions wages collective agreements

Codes JEL : J31, J50

\footnotetext{
* MSC graduate, Université de Montréal

† Professor, Economics Department, Université de Montréal, francois.vaillancourt@ umontreal.ca
} 


\section{Introduction}

There have been a large number of empirical studies on the impact of being unionized or not on wages, with evidence largely in favour of the existence of a union wage premium. Examples of such studies include Budd and $\mathrm{Na}$ (2000) who find a wage premium of $11.4 \%$ (OLS estimate), Schmitt (2008) that finds a similar premium of $11.9 \%$, but with variations across the wage distribution, from $20.6 \%$ for the low-wage workers in the $10^{\text {th }}$ percentile to $6.1 \%$ for the high-wage workers in the $90^{\text {th }}$ percentile and Even and Macpherson (2009) that show that the wage premium paid by large firms fell over the past 20 years. Results for Canada such as those of Fang and Verma (2002) also show the existence of a union wage premium.

The purpose of this note is to examine the effect of belonging to a specific union on negotiated wage increases, given unionisation status. This is of interest because unions spend resources (time and money) trying to convince unionized workers to both not switch or switch from one union to another, arguing that membership in their union yields higher benefits. Yet there seems to have been no studies of the benefits of belonging to a specific union. What we have found are studies that examine the impact of specific unions on the expected duration of a strike (Gunderson and Melino, 1990) or on strike incidence (Gunderson, Kervin and Reid, 1989) for the case of Canada. Both studies use collective agreements as the unit of observation and include as control variables of little interest to the authors five dummy variables for specific unions (all others are the omitted group): these are for Steelworkers; Food and commercial workers; Autoworkers; Teamsters and Carpenters and joiners The first study shows that strikes by bargaining units of the Steelworkers and Food and commercial workers have a shorter duration, everything else equal. The second study shows that bargaining units of the Teamsters and Canadian auto workers unions are more likely to go on strike, again everything else equal. Thus different unions have different behaviour with respect to strikes; $\mathrm{Bu}$ do they have different results in terms of wages? This is what we now examine. 


\section{Data, model and variables}

The data consist of collective agreements with more than 500 employees, which were signed in Quebec or Ontario during the 1985-2007 period ${ }^{1}$. These were provided by Human Resources and Skill Development Canada. They are mainly for sectors under federal jurisdiction but also include some large provincial ones. These are the two largest provinces in Canada, accounting for $63 \%$ of the collective agreements recorded. We estimate results for each province separately since labour laws differ between the two provinces. In particular, Quebec has a provision against hiring outside workers (strike breakers or scabs) during strikes that is not present in the Ontario labour code.

The model used in this note is a standard wage equation, used with similar data for an earlier period and without union variables in Vaillancourt and Marceau (1990). More precisely, the equation estimated is; $\mathrm{W}_{\mathrm{i}}=\beta_{0}+\beta_{1} \mathrm{AFLCIO}+\beta_{2} \mathrm{CtWCLC}+\beta_{3} \mathrm{CSN}+$ $\beta_{4}$ IndUnion $+\beta_{5} \mathrm{CPI}_{\mathrm{i}}+\beta_{6} \mathrm{COLA}+\beta_{7}$ Unemployment $_{\mathrm{i}}+\Sigma_{\mathrm{j}=10} \beta_{\mathrm{j}}$ Industry $_{\mathrm{i}}$.

$\mathrm{W}$ is the negotiated rate of increase of base wages, annualized.

AFLCIO, CtWCLC, CSN, IndUnion are four dichotomous variables that are equal to one when a collective agreement is with that particular union.

CPI is the inflation in the consumer price index two quarters before the collective agreements.

COLA is a dichotomous variable that is equal to one to indicate the presence of cost of living agreements in the collective agreement.

Unemployment is the unemployment rate two quarters before the collective agreements.

\footnotetext{
${ }^{1}$ The database is known as Negotech .See http://www.hrsdc.gc.ca/eng/labour/labour relations/info analysis/index.shtml for more details and access to the data.
} 
Industry represents the eighteen industrial dichotomous variables. Food and beverages is the reference industry, excluded in the regressions. The industries are: I2: construction; I3: textile, clothing and leather; I4: wood products, paper and printing; I5: petroleum, coal and chemical products; I6: plastics and rubber products; I7: non-metallic mineral products; I8: primary metals; I9: metal products; I10: machinery; I11: computer and electronic; I12: electrical equipment and appliances; I13: transportation equipment; I14: wholesaler and distributors; I15: grocery stores; I16: transports; I17: broadcasting and telecommunications; I18: administrative and support services; I19: accommodation services.

Table 1 below summarizes the importance on the different unions. In Ontario, the AFLCIO is by far the dominant union with $59.5 \%$ of collective agreements signed while in Quebec, it accounts for only $36.7 \%$ of collective agreements. The second union in both provinces is the CLC but one notes that the Quebec based CSN accounts for $18 \%$ of agreements in that province.

\section{Table 1}

*Number of collective agreements by union, Ontario and Quebec, 1985-2007

\begin{tabular}{|l|l|l|l|}
\hline Union & Abbreviations & Quebec & Ontario \\
\hline Canadian labour congress & CLC (CTC) & 182 & 423 \\
\hline $\begin{array}{l}\text { The american federation of labour } \\
\text { and congress of industrial } \\
\text { organization }\end{array}$ & AFL-CIO & 232 & 803 \\
\hline Change to win & $\begin{array}{l}\text { CtW/CLC } \\
\text { (Ctw/CTC) }\end{array}$ & 5 & 44 \\
\hline $\begin{array}{l}\text { Confédération des syndicats } \\
\text { nationaux }\end{array}$ & CSN & 114 & 0 \\
\hline Independent union & Ind. Union. & 99 & 79 \\
\hline
\end{tabular}

Source: authors 


\section{Results}

Table 2 presents a fist set of regression results.

\section{Table 2}

The effect of a specific union on wage increases, Ontario and Quebec, 1985-2007.

\begin{tabular}{|c|c|c|}
\hline $\begin{array}{l}\text { Negotiated wage increase as the } \\
\text { dependent variable. }\end{array}$ & $\begin{array}{l}\text { (1) } \\
\text { (Quebec) }\end{array}$ & $\begin{array}{l}\text { (2) } \\
\text { (Ontario) } \\
\end{array}$ \\
\hline Constant & $\begin{array}{l}2,777 \\
(6,14)\end{array}$ & $\begin{array}{l}3,230 \\
(9,33)\end{array}$ \\
\hline \multicolumn{3}{|l|}{ Omitted union is CLC } \\
\hline AFL-CIO/CLC union & $\begin{array}{l}0,360 \\
(2,00)\end{array}$ & $\begin{array}{l}0,052 \\
(0,38)\end{array}$ \\
\hline $\mathrm{CtW} / \mathrm{CLC}$ union & $\begin{array}{l}-0,378 \\
(0,56)\end{array}$ & $\begin{array}{l}-0,406 \\
(1,43)\end{array}$ \\
\hline CSN union & $\begin{array}{l}-0,148 \\
(0,82)\end{array}$ & --- \\
\hline Ind. Union & $\begin{array}{l}0,178 \\
(0,83)\end{array}$ & $\begin{array}{l}0,230 \\
(1,07)\end{array}$ \\
\hline Inflation in the CPI & $\begin{array}{l}0,509 \\
(14,52)\end{array}$ & $\begin{array}{l}0,517 \\
(15,90)\end{array}$ \\
\hline Cost of living agreements & $\begin{array}{l}-0,473 \\
(3,11)\end{array}$ & $\begin{array}{l}-0,888 \\
(5,63)\end{array}$ \\
\hline Unemployment & $\begin{array}{l}-0,089 \\
(2,61)\end{array}$ & $\begin{array}{l}-0,218 \\
(7,23)\end{array}$ \\
\hline $\begin{array}{l}\text { Omitted sector is Food and } \\
\text { beverages }\end{array}$ & & \\
\hline Construction & $\begin{array}{l}-0,724 \\
(2,08)\end{array}$ & $\begin{array}{l}0,560 \\
(3,20)\end{array}$ \\
\hline Textile, clothing and leather & $\begin{array}{l}-1,046 \\
(3,98)\end{array}$ & $\begin{array}{l}0,305 \\
(0,87)\end{array}$ \\
\hline Wood products, paper and printing & $\begin{array}{l}-0,149 \\
(0,56)\end{array}$ & $\begin{array}{l}0,157 \\
(0,60)\end{array}$ \\
\hline $\begin{array}{l}\text { Petroleum, coal and chemical } \\
\text { products }\end{array}$ & $\begin{array}{l}-0,075 \\
(0,21)\end{array}$ & $\begin{array}{l}0,064 \\
(0,20)\end{array}$ \\
\hline Plastics and rubber products & $\begin{array}{l}-1,320 \\
(3,99)\end{array}$ & $\begin{array}{l}-0,286 \\
(0,93)\end{array}$ \\
\hline
\end{tabular}




\begin{tabular}{|c|c|c|}
\hline & $\begin{array}{l}\text { (1) } \\
\text { (Quebec) }\end{array}$ & $\begin{array}{l}(2) \\
\text { (Ontario) }\end{array}$ \\
\hline Non-metallic mineral products & $\begin{array}{c}-1,046 \\
(2,30)\end{array}$ & $\begin{array}{l}0,050 \\
(0,13)\end{array}$ \\
\hline Primary metals & $\begin{array}{l}-0,516 \\
(1,96)\end{array}$ & $\begin{array}{l}-1,543 \\
(5,43)\end{array}$ \\
\hline Metal products & $\begin{array}{l}-0,677 \\
(1,20)\end{array}$ & $\begin{array}{l}-0,313 \\
(0,91)\end{array}$ \\
\hline Machinery & $\begin{array}{l}-0,164 \\
(0,16)\end{array}$ & $\begin{array}{l}-0,721 \\
(2,35)\end{array}$ \\
\hline Computer and electronic & $\begin{array}{l}-0,629 \\
(1,80)\end{array}$ & $\begin{array}{l}0,176 \\
(0,51)\end{array}$ \\
\hline Electrical equipment and appliances & $\begin{array}{l}-0,799 \\
(2,24)\end{array}$ & $\begin{array}{l}-0,650 \\
(2,07)\end{array}$ \\
\hline Transportation equipment & $\begin{array}{l}-0,312 \\
(1,20)\end{array}$ & $\begin{array}{l}-0,280 \\
(1,28)\end{array}$ \\
\hline Wholesaler and distributors & $\begin{array}{l}-0,387 \\
(1,18)\end{array}$ & $\begin{array}{l}-0,048 \\
(0,15)\end{array}$ \\
\hline Grocery stores & $\begin{array}{l}-1,695 \\
(3,65)\end{array}$ & $\begin{array}{l}-0,340 \\
(1,63)\end{array}$ \\
\hline Transports & $\begin{array}{l}-0,593 \\
(1,36)\end{array}$ & $\begin{array}{l}-0,696 \\
(1,96)\end{array}$ \\
\hline $\begin{array}{l}\text { Broadcasting and } \\
\text { telecommunications }\end{array}$ & $\begin{array}{l}-0,541 \\
(1,36)\end{array}$ & $\begin{array}{l}-0,470 \\
(0,69)\end{array}$ \\
\hline Administrative and support services & $\begin{array}{l}-0,405 \\
(1,23)\end{array}$ & $\begin{array}{l}-0,458 \\
(1,17)\end{array}$ \\
\hline Accommodation services & $\begin{array}{l}0,984 \\
(2,59)\end{array}$ & $\begin{array}{l}0,557 \\
(1,73)\end{array}$ \\
\hline $\mathrm{F}$ & 12,54 & 40,22 \\
\hline $\mathrm{R}^{2}$ & 0,341 & 0,422 \\
\hline $\mathrm{N}$ & 632 & 1349 \\
\hline
\end{tabular}


Looking first at the non union variables, we find the expected impacts of unemployment $(-)$, inflation (+) and of the presence of a cost of living clause (-) on the negotiated wage growth. We find that only one (AFL-CIO in Quebec) of the dichotomous union variables is significant at a $5 \%$ confidence level. But perhaps our results hide some sectoral differences. We thus estimate our equation anew for the four Ontario sectors for which we have more than 100 observations, a cut-off used to ensure a reasonable sample size. This results in no sectoral estimations for Quebec. We report the results in table 3; we find no impact of a specific union on wage growth.

The effect of a specific union on wage increases in Ontario, 1985-2007.

\begin{tabular}{|c|c|c|c|c|}
\hline $\begin{array}{l}\text { Negotiated wage increase } \\
\text { as the dependent } \\
\text { variable. }\end{array}$ & $\begin{array}{l}\text { Food and } \\
\text { beverage }\end{array}$ & Construction & $\begin{array}{l}\text { Transportation } \\
\text { equipment }\end{array}$ & $\begin{array}{l}\text { Grocery } \\
\text { Stores }\end{array}$ \\
\hline Constant & $\begin{array}{l}0,466 \\
(0,46)\end{array}$ & $\begin{array}{l}4,567 \\
(5,49)\end{array}$ & $\begin{array}{l}3,824 \\
(6,14)\end{array}$ & $\begin{array}{l}-0,872 \\
(0,66)\end{array}$ \\
\hline \multicolumn{5}{|l|}{ Omitted union is CLC } \\
\hline AFL-CIO/CLC union & $\begin{array}{l}-0,563 \\
(1,34)\end{array}$ & $\begin{array}{l}-0,285 \\
(0,45)\end{array}$ & $\begin{array}{l}0,184 \\
(0,62)\end{array}$ & $\begin{array}{l}0,572 \\
(1,06)\end{array}$ \\
\hline $\mathrm{CtW} / \mathrm{CLC}$ union & $\begin{array}{l}-0,114 \\
(0,16)\end{array}$ & $\begin{array}{l}0,092 \\
(0,12)\end{array}$ & - & $\begin{array}{l}-0,176 \\
(0,24)\end{array}$ \\
\hline CSN union & - & - & - & - \\
\hline Ind. Union & $\begin{array}{l}-0,646 \\
(0,96)\end{array}$ & $\begin{array}{l}-0,546 \\
(0,78)\end{array}$ & $\begin{array}{l}0,158 \\
(0,30)\end{array}$ & - \\
\hline Inflation in the CPI & $\begin{array}{l}0,946 \\
(9,07)\end{array}$ & $\begin{array}{l}0,779 \\
(13,30)\end{array}$ & $\begin{array}{l}0,030 \\
(0,44)\end{array}$ & $\begin{array}{l}1,118 \\
(7,27)\end{array}$ \\
\hline Cost of living agreements & $\begin{array}{l}-0,363 \\
(0,96)\end{array}$ & - & $\begin{array}{l}-1,246 \\
(4,15)\end{array}$ & $\begin{array}{l}-0,295 \\
(0,58)\end{array}$ \\
\hline Unemployment & $\begin{array}{l}0,022 \\
(0,24)\end{array}$ & $\begin{array}{l}-0,385 \\
(6,64)\end{array}$ & $\begin{array}{l}-0,115 \\
(1,81)\end{array}$ & $\begin{array}{l}-0,003 \\
(0,02)\end{array}$ \\
\hline $\mathrm{F}$ & 16,82 & 85,51 & 7,88 & 28,35 \\
\hline $\mathrm{R}^{2}$ & 0,481 & 0,535 & 0,153 & 0,548 \\
\hline $\mathrm{N}$ & 116 & 377 & 224 & 123 \\
\hline
\end{tabular}




\section{Conclusion}

Empirical studies on the effect of union on wages growth have been focusing on union wage premium. This note examined a different question, does what union represents workers, controlling for economic environment and sectoral variables matter in terms of wage growth? For the period of 1985-2007 in Quebec and Ontario, we find no convincing evidence that what union represents worker matters in terms of wage growth.

\section{References}

Budd, J. W. And Na, I. (2000), “The Union Membership Wage Premium for Employees Covered by Collective Bargaining Agreements", Journal of Labour Economics, Vol. 18, No. 4, pp.783-807.

Even, W. E. And Macpherson, D. A. (2009), "Is Bigger Still Better? The Decline of the Wage Premium at Large Firms", The Institute for the Study of Labour (IZA) in Bonn Germany, Discussion Paper No. 4082, pp.1-29.

Fang, T. and Anil, V. (2002) "Union Wage Premium" Perspective on Labour and Income 14 (4) 17-23 Statistics Canada

Gunderson, M. and Melino, A. (1990), "The Effects of Public Policy on Strike Duration", Journal of Labour Economics, Vol. 8, No. 3, pp. 295-316.

Gunderson, M., Kervin, J. And Reid, F. (1989), “The effect of labour relations legislation on strike incidence”, Canadian Journal of Economics, Vol. 22, No.4, pp. 779-794.

Schmitt, J. (2008), “The Union Wage Advantage for Low-Wage Workers”, Center For Economic and Policy Research, Washington DC, pp. 1-10.

Vaillancourt, F. and Marceau, N. (1990), "Do general and firm-specific employer payroll taxes have the same incidence? Theory and evidence", Economics Letters, No. 34, p178 